\title{
Diagnosa Komunikasi Brand Activation Dan Media Digital Atas Eksistensi Brand Studio Rekaman Lokananta
}

\author{
Gregorius Genep Sukendro, Nigar Pandrianto \\ Fakultas Ilmu Komunikasi, Universitas Tarumanagara \\ Jl. Letjen S Parman No 1, Jakarta Barat 11440 \\ geneps@ fikom.untar.ac.id, nigarp@fikom.untar.ac.id
}

Masuk tanggal : 26-06-2019, revisi tanggal : 13-08-2019, diterima untuk diterbitkan tanggal : 13-08-2019

\begin{abstract}
The use of digital-based communication media and brand activation by the industry can attract the attention of potential consumers or customers. Even from these two activities, consumer trust and loyalty to the brand can be achieved. This research will look at how digital-based brand activation and communication can successfully attract consumers' attention. Therefore a number of marketing communication and marketing theories will be used in this study to dissect and photograph the research object. To analyze data, this research will use SOSTAC analysis. In addition to conducting observations and literature studies, researchers also conducted interviews with industry parties. Therefore this research is expected to be a reference in industrial development by utilizing digital-based communication and brand activation. The results of the study showed Lokananta still had to maximize the use of digital media as a form of brand activation to maintain brand existence.
\end{abstract}

Keywords: brand activation, digital media, marketing communication.

\begin{abstract}
Abstrak
Pemanfaatan media komunikasi berbasis digital dan brand activation oleh industri dapat menarik perhatian calon konsumen atau pelanggan. Bahkan dari kedua kegiatan ini kepercayaan dan loyalitas konsumen kepada brand dapat dicapai. Penelitian ini akan melihat bagaimana brand activation dan komunikasi berbasis digital berhasil dapat menarik perhatian konsumen. Oleh karena itu sejumlah teori komunikasi pemasaran dan pemasaran akan digunakan dalam penelitian ini untuk membedah dan memotret obyek penelitian. Untuk menganalisa data, penelitian ini akan akan menggunakan analisis SOSTAC. Selain melakukan observasi dan studi pustaka, peneliti juga melakukan wawancara dengan pihak industri. Oleh karenanya penelitian ini diharapkan bisa menjadi acuan dalam pengembangan industri dengan memanfaatkan komunikasi berbasis digital dan brand activation. Hasil dari penelitian menunjukkan Lokananta masih harus memaksimalkan penggunaan media digital sebagai bentuk brand activation untuk mempertahankan eksistensi brand.
\end{abstract}

Kata Kunci: brand activation, media digital, komunikasi pemasaran.

\section{Pendahuluan}

Penggunaan media digital sebagai salah satu medium komunikasi semakin mendapat tempat dalam berbagai industri. Hal ini dipicu oleh meluasnya 
penggunaan perangkat komunikasi berbasis digital yang juga kian meluas dan semakin terjangkaunya biaya akses data internet. Salah satu indikasinya adalah hasil survey yang dilakukan oleh majalah Marketeers yang dikeluarkan pada bulan Agustus 2017 lalu.

Dari hasil survey tersebut terlihat tren pemanfaatan media digital sebagai sumber informasi oleh anak muda cukup tinggi terutama di kota-kota besar. Di Jabodetabek misalnya, penggunaan internet sebagai sumber informasi tercatat sangat tinggi, yakni mencapai 60\% (n: 900) ketimbang sumber dari televisi maupun surat kabar. Angka yang sama didapati juga di Surabaya (n: 780). Lalu di Semarang catatan yang sama mencapai 53\% (n:596), diikuti berturut-turut di kotakota Manado (52\%, n: 584), dan Bandung (49\%, n:775). Meskipun di beberapa kota terlihat persentase penggunaan televisi sebagai sumber informasi berada di atas internet, namun persentase penggunaan internet rata-rata berada di atas penggunaan surat kabar sebagai sumber akses informasi. Hal di atas memperlihatkan komunikasi yang dilakukan melalui medium digital kini juga memiliki peluang yang besar untuk menarik perhatian target konsumen selain media-media konvensional.

Fakta ini ternyata telah mendorong banyak perusahaan maupun lembaga ikut memanfaatkan media digital sebagai sarana berkomunikasi dengan konsumen. Mereka bergegas melakukan ini agar selalu dapat memelihara engagement dengan konsumen yang terus berubah dari waktu ke waktu. Mereka yakin tanpa langkah-langkah ini sulit untuk dapat terus menjaga relasi yang baik dengan calon konsumen. Tanpa langlah-langkah ini mereka berharap untuk terhindar dari dampak disruptif. Mereka tidak mau menjadi pemain lama yang tiba-tiba harus bergeser karena kehadiran media baru yang ternyata mensyaratkan perubahan yang mendasar. Sekuat apa pun brand loyalty yang telah dibangun oleh incumbent melalui strategi komunikasi pemasaran konvesional, posisi incumbent tetap akan terancam pada era yang serba disruptif ini (Khasali, 2017)

Namun di tengah riuhnya penggunaan platform digital sebagai medium komunikasi, hal yang paling harus diperhatikan dalam platform ini adalah formulasi konten atau pesan yang akan dikomunikasikan kepada audiens. Padahal pesan atau konten merupakan unsur komunikasi yang sangat penting (Cangara, 2017) termasuk dalam komunikasi pemasaran. Konsekuensinya, pesan harus dirancang sedemikian agar dapat menghasilkan efek yang diharapkan.

Namu, selain medium komunikasi digital seperti yang dipaparkan di atas, komunikasi dalam bentuk-bentuk lain juga dapat dilakukan untuk memelihara loyalitas pelanggan, misalnya saja aktivasi. Aktivasi dalam konteks komunikasi pemasaran adalah kegiatan mendekatkan brand atau merek dengan penggunanya melalui berbagai aktivitas yang menarik perhatian konsumen. Saat ini, selain melakukan komunikasi melalui iklan, banyak brand yang memilih untuk menggunakan brand activation.

Brand activation sendiri digambar sebagai suatu bentuk kegiatan promosi merek lebih dekat ke merek dengan penggunanya melalui berbagai kegiatan yang menarik perhatian konsumen, dengan kata lain aktivasi merek adalah interaksi antara merek dengan konsumen atau calon konsumen melalui berbagai kegiatan, baik online dan offline (www.brightstars.co.id). Beberapa keunggulan brand 
activation adalah adanya interaksi langsung antara brand dengan konsumen. Hal ini tentu akan membuat hubungan konsumen terhadap brand semakin erat. Apalagi jika hal ini dikatkan langsung dengan experience calon konsumen. Ketika hubungan sudah semakin erat maka konsumen akan dengan senang hati merekomendasikan brand yang dipercayanya kepada orang lain.

Pemanfaatan brand activation sebagai bentuk komunikasi pemasaran sudah lama digunakan oleh berbagai brand untuk memperkenalkan serta mendekatkan brand ke kepada konsumen. Di tahun 2003 misanya Lipton Ice Tea pernah menyelenggarakan kompetisi band yang diikuti oleh puluhan band dan menarik ribuan pengunjung. Lalu ada tahun 2015 CIMB menggelar The Color Runs yang berhasil menarik perhatian ribuan pelari untuk bergabung dalam komptisi maraton sejauh lima kilometer di Jakarta.

Tentu saja tak hanya kegiatan berskala besar seperti itu yang dapat digolongkan sebagai brand activation. Kegiatan berskala lebih kecil pun, yang mungkin hanya diikuti oleh puluhan peserta, juga dapat digolongkan pada kegiatan brand activation. Misalnya saja demo memasakan yang hanya dihadiri oleh 70 orang di lingkungan terbatas. Sepanjang kegiatan tersebut melibatkan brand, maka kegiatan itu dapat digolongkan sebagai brand activation.

Hal yang sama juga dilakukan oleh perusahaan rekaman Lokananta yang berlokasi di Solo, Jawa Tengah. Dari hasil penelusuran, perusahaan rekaman tertua di Indonesia ini telah menggunakan platform digital sebagai medium komunikasi. Dari hasil pengamatan terlihat perusahaan rekaman ini telah memiliki account Facebook, Twitter, dan Instagram yang hingga bulan Agustus 2017 masih aktif berinteraksi dengan para followernya. Selain itu ada juga website www.lokanantamusik.com. Namun pada tanggal 9 September 2017 situs ini tidak dapat diakses. Melalui media-media digital inilah Lokananta berinterkasi dengan para follower-nya yang terdiri dari pecinta, penikmat, produser, hingga anggota komunitas musik.

Tidak hanya itu, berbagai brand activation pun diselenggarakan oleh perusahaan yang telah berusia lebih dari 60 tahun itu. Ini pun menarik perhatian para pecinta musik Indonesia. Tidak mengherankan jika perusahaan yang sempat luput dari perhatian publik itu kini semakin menarik bagi banyak orang.

Namun di sisi lain Lokananta masih menyisakan cerita suram. Seperti dilaporkan oleh Kompas misalnya, perusahaan ini masih menemui masalah. Kompas menggambarkannya sebagai berikut, debu-debu serasa menyelundup ke paru-paru. Bahkan suhu ruangannya cukup panas. Terlihat tidak mendukung penyimpangan koleksi piringan hitam. Kondisi ini jika tidak dibenahi akan berakibat pada kerusakan koleksi yang disimpan di sini. Namun tak perlu menunggu lama, kerusakannya dapat langsung terlihat. Sampul piringan hitam sudah dimakan rayap dan menguning. Koleksi-koleksi bersejarah ini seperti terlupakan. Namun Bekti kembali menjelaskan bahwa status Lokananta saat ini tidak jelas. Bahkan untuk kegiatan operasional hariannya, para pegawai Lokananta bergantung dari penjualan kaset dan CD. 
Laporan Kompas tersebut menunjukkan, kegatan komunikasi yang dilakukan oleh Lokananta belum menghasilkan perubahan perusahaan ke arah yang lebih baik secara siginifikan. Itu berarti Lokananta masih harus melakukan banyak hal agar eksistensinya dapat terus bertahan.

Dari identifikasi masalah yang dikemukakan di ataas, masalah yang dapat dirumuskan pada penelitian ini adalah, bagaimana komunikasi berbasis digital dan brand activation harus dilakukan agar eksistensi Lokananta dapat terus bertahan. Penelitian ini bertujuan untuk melihat strategi komunikasi yang telah diaplikasikan oleh Lokananta utuk memperkenalkan brand Lokananta itu sendiri untuk menarik perhatian sekaligus mempertahankan engagament para pelanggannnya.

\section{Era Digital dan Perubahan Lanskap Bisnis}

Perubahan-perubahan yang terjadi dalam masyarakat, terutama karena perkembangan teknologi komunikasi (baca digital), telah membawa perubahan besar pada pola kehidupan masyarakat, mulai dari pola berkomunikasi, pola berinteraksi, sampai pola menentukan pembelian.

Rhenald Kasali dalam Disruptive (2017) menunjukkan secara jelas bagaimana perubahan-perubahan itu terjadi-dalam fase tertentu telah membuat perusahan incumbent gulung tikar. Berikut adalah konsekuensi-konsekuensi kemajuan teknologi dalam kehidupan masyarakat:

1. Teknologi telah mengubaha manusia dari peradaban time series menjadi real time. Jika sebelumnya orang menggunakan masa lalu untuk memprediksi masa depan, maka kini data yang ada pada hari ini langsung terolah dalam big data dan secepat itu pula dapat disimpulkan dan ditindak lanjuti.

2. Di masa lalu seseorang yang ingin berbisnis harus memilikinnya sendiri. Namun di masa kini orang yang ingin berbisnis tidak harus memiliki semuanya. Sebab kini masyarakat hidup pada era dimana aset-aset konsumtif terbuka untuk digunakan secara bersama-sama dan saling berbagi.

3. Teknologi masa lalu tidak memungkinkan kesegeraan. Sekarang yang berlaku adalah on-demand. Saat konsumen menghendaki, produk atau layanan tersebut harus sudah ada. Teknologi dan algoritma big data sangat memmungkinkan hal itu.

4. Kurva penawaran-permintaan yang sebelumnya bersifat tunggal kini berubah menjadi sesutu yang bersifat kolektif, artiya akan menyangkut ribuan jejaring. Jadi, penawaran akan selalu menyangkut jaringan ribuan pihak lain, demikian juga dengan permintaan.

5. Karena teknologi, musuh dan kompetitor juag serig kali tidadk terlihat. Perusahaan taksi misalnya tidak pernah menduga bahwa kompetitor mereka sekarang bukanlah perusahaan taksi lain, tetapai justru jaringan orang per orang yang memiliki kendaraan pribadi. 
Apa yang disampaikan di atas memperlihatkan bahwa perkembangan teknologi digital sulit untuk ditolak. Mau tidak mau setiap orang harus menerimanya dengan beragam konsekuensi. Inipun harus mendorong perusahaan untuk menemukan cara atau strategi baru dalam menjalankan bisnisnya, termasuk cara baru dalam berkomunikasi. Apalagi konsumen yang juga terus berubah (Khasali, 2017). Bahkan tidak jarang perubahan ini tidak terdeteksi oleh produsen. Di sini terjadi sofistifikasi yang hebat dalam pola demand. Konsumen tidak hanya semakin cerdas, tetapi juga makin percaya diri. Konsumen Indonesia sendiri termasuk ke dalam konsumen yang memiliki tingkat percaya diri yang tinggi (Lim, 2016). Bagi pakar marketing, perubahan konsumen ini sudah merupakan harus dicermati secara serius jika oleh banyak produsen. Malah jika ditelaah ada tiga kategori konsumen yang harus benar-benar mendapat perhatian yakni perempuan, anak muda, dan netizen (Kertajaya, 2017)

\section{Brand Activation}

Brand activation adalah kegiatan komunikasi yang dilakukan oleh brand dengan konsumen yang dapat membangun sebuah relasi. Namun relasi ini harus dapat dibangaun dengan melibatkan berbagai sumber daya dengan cara-cara yang kreatif sehingga konsumen dapat merasakan pengalaman yang mendalam dengan brand. Belakangan ada juga yang menyebut kegiatan ini dengan experiental marketing (Saeed, 2015). Prinsip-prinsip brand activation antara lain:

a. Mengadopsi dengan pendekatan ide besar (big idea) yang menarik perhatian konsumen

b. Menghadirkan spirit sebuah brand dengan beragam cara yang kreatif

c. Menghidupkan passion konsumen atas sebuah brand

d. Menghadirkan ide yang dapat memotovasi konsumen

e. Terjalin relasi seketika antara brand dan konsumen pada waktu, tempat dan cara yang unik

f. Membangun komitmen konsumen terhadap brand

\section{Komunikasi Berbasis Digital}

Perkembangan teknologi digital telah membuat komunikasi semakin tidak memiliki batas. Perkembangan ini pula yang telah mendorong munculnya media baru yang mendekatkan komunikasi interaktif. Media baru sendiri menurut definisi www.pcmag.com adalah bentuk komunikasi dalam dunia digital terutama melalui jaringan internet baik menggunakan komputer desktop, laptop, smart phone ataupun tablet.

Seiring perkembangan zaman yang semakin tumbuh pesat, banyak jenisjenis media baru yang bermunculan di masyarakat yang mengubah spektrum dari berbagai kemungkinan tentang sosio teknologi yang berdampak terhadap komunikasi publik. Banyaknya media sosial yang bermunculan seperti facebook, twitter, instagram, dan lain-lain merupakan media baru yang membuat orang bisa berkomunikasi dan berbagi dengan teman bahkan dengan orang lain yang memiliki akun media sosial yang sama. 
Media sosial adalah media yang banyak digunakan oleh masyarakat sekarang ini untuk berkomunikasi. Media sosial memiliki fungsi untuk dapat mendukung interaksi sosial bagi para penggunanya. Media sosial dapat digunakan untuk berinteraksi dengan teman, berbagi informasi, juga bisa mendapatkan teman-teman baru yang sama-sama menggunakan akun media sosial tersebut. Mayfield mendefinisikan media sosial sebagai pemahaman terbaik dari kelompok jenis baru media online yang mencakup karakter-karakter partisipasi, keterbukaan, percakapan, komunitas, dan konektivitas (Yulianita, 2011).

\section{Komunikasi Pemasaran}

Menurut Stanton yang dikutip oleh Djaslim Saladin dan Yevis Marti Oesman dalam buku Intisari Pemasaran dan Unsur-Unsur Pemasaran (2002), menjelaskan komunikasi pemasaran adalah kombinasi dari penjualan tata muka, periklanan, promosi penjualan, publisitas, dan hubungan masyarakat yang membantu pencapaian tujuan perusahaan.

Dari pengertian di atas dapat disimpulkan bahwa komunikasi pemasaran adalah cara untuk mengkomunikasikan produk kepada konsumen dengan penggunaan unsur-unsur promosi untuk mencapai tujuan perusahaan. Komunikasi pemasaran disebut juga bauran promosi yang merupakan alat efektif untuk berkomunikasi dengan para pelanggan (baik konsumen atau perantara). Komunikasi pemasaran atau bauran promosi ini perlu ditangani secara cermat karena masalahnya bukan hanya menyangkut besarnya biaya yang digunakan. Dalam memasarkan produknya, perusahaan memerlukan suatu komunikasi maka konsumen dapat mengetahui produk yang ditawarkan oleh perusahaan.

Menurut Best dalam buku Pemasaran Strategik yang dikutip Ujang Surmawan, dkk (2010), tugas dari komunikasi pemasaran adalah sebagai berikut: (1) Membangun kesadaran, membangun suatu tindak kepedulian tertentu terhadap informasi penting yang disampaikan berkenaan dengan organisasi dan produk atau jasanya; (2) Penetrasi pesan, mempertahankan tingkat keberadaan tertentu yang diharapkan dari citra (image), manfaat utama, dan pengenalan nama dari waktu ke waktu di memori konsumen; (3) Rangsangan melakukan tindakan, memotivasi konsumen yang disasar agar secara mengambil tindakkan tertentu karena penetrasi pesan dan tindakkan hanya dapat terjadi setelah konsumen memiliki tingkat kepedulian tertentu, perusahaan perlu terlebih dahulu membangun kesadaran dan pemahaman sebelum melangkah kepada tujuan komunikasi pemasaran yang lainnya.

\section{Analisis SOSTAC}

Dalam penelitian ini, Penulis menggunakan analisis SOSTAC untuk mengidentifikasi dan menganalisa persoalan-persoalan pada suatu pemasaran produk atau perusahaan kemudian dibahas satu persatu mulai dari Situation Analysis, Objectives, Strategy, Tactics, Action dan yang terakhir Control disingkat menjadi (SOSTAC). 


\section{Situation}

Merupakan tahap pertama pada metode SOSTAC dimana penulis akan menganalisa situasi dari industri rekaman Lokananta di Solo dan pengamat dan penggiat musik di Yogyakarta.

\section{Objectives}

Setelah penulis mengetahui posisi perusahaan saat ini selanjutnya penulis mencari tahu tujuan atau visi misi yang ingin dicapai industri rekaman. Tahapan ini sangat krusial karena sebagai panduan untuk bagaimana menentukan strategistrategi yang cocok dengan harapan target pemasaran yang diinginkan perusahaan serta menjadi fokus terhadap tahapan mencapai goal atau tujuan perusahaan tersebut sehingga tidak melenceng keluar outline tujuan perusahaan.

\section{Strategy}

Pada tahap ketiga ini, penulis berupaya mengungkapkan bagaimana industri kreatif dapat mencapai tujuan yang telah ditentukan dengan taktik-taktik kegiatan promosi seperti periklanan, promosi penjualan dan kinerja. Aspek-aspek penting sebagai bahan perhatian untuk penulis dalam tahap ini adalah seperti product, price, promotion, positioning, place, business model, segmentation market, dan targeting.

\section{Tactics}

Merupakan tahapan menjabarkan implementasi taktik yang paling sesuai pada eksekusi di lapangan nantinya berdasarkan strategi yang telah disusun oleh pihak industri kreatif.

\section{Actions}

Setelah taktik selesai ditetapkan maka penulis akan menganalisis bagaimana industri kreatif tersebut menjalankan taktik tersebut di lapangan market place yang sesungguhnya.

\section{Control}

Pada tahap terakhir yaitu proses control, penulis akan mengevaluasi dan memeriksa secara berkala apakah action sudah berjalan maksimal dan berhasil, dan jika masih belum hal-hal apa yang menjadi kendala supaya dapat menjadi bahan evaluasi.

\section{Metode Penelitian}

Metode penelitian yang digunakan dalam penelitian ini adalah penelitan yang bersifat kualitatif. Istilah kualitatif sendiri mempunyai makna yang beragam menurut ahli. Creswell (Semiawan, 2010) mendefinisikan penelitian kualitatif sebagai suatu pendekatan atau penelusuran untuk mengeksplorasi dan memahami suatu gejala sentral. Untuk mengerti gejala sentral tersebut, peneliti sebagai partisipan mewawancarai narasumber dengan mengajukan pertanyaan yang umum dan lebih luas. 
Jenis penelitian yang digunakan dalam penelitian ini adalah penelitian yang sifatnya deskriptif. Metode deskriptif ini menggambarkan secara sistematis fakta atau karakteristik populasi tertentu secara faktual dan cermat. Jadi, metode penelitian deskriptif ini antara lain adalah mengumpulkan informasi yang aktual secara rinci serta melihat gejala-gejala yang ada di dalam penelitian selanjutnya mengidentifikasi masalah tersebut data dari hasil penelitian ini disusun secara kualitatif. Tujuan metode penelitian ini lebih kepada membuat gambaran secara sistematis, faktual, dan akurat tentang fakta-fakta dan sifat-sifat objek tertentu.

Untuk memperoleh dan mengumpulkan data akan dilakukan penelitian di. Periode waktu penelitian dan data yang diperoleh dalam penelitian ini adalah di studio rekaman Lokananta, Solo Dalam penelitian ini, metode pengumpulan data adalah teknik atau cara-cara yang dapat digunakan dalam riset untuk mengumpulkan informasi yang diperlukan untuk memperoleh kebenaran. Teknik pengumpulan data yang akan digunakan dalam penelitian ini melalui beberapa cara, yaitu: wawancara dan observasi.

\section{Hasil Penemuan Dan Diskusi}

\section{Lokananta}

Lokananta merupakan perusahaan rekaman musik (label) pertama dan satu-satunya milik negara yang didirikan pada tanggal 29 Oktober 1956 dan berlokasi di Surakarta-Solo, Jawa Tengah. Sejak berdirinya, Lokananta mempunyai dua tugas besar, yaitu produksi dan duplikasi piringan hitam dan kemudian cassette audio. Pada tahun 1958, piringan hitam mulai dicoba untuk dipasarkan kepada umum melalui RRI.

Berdiri sejak tahun 1956, Lokananta awalnya mengemban tugas untuk memproduksi sekaligus mendistribusikan materi siaran untuk Radio Republik Indonesia dalam bentuk piringan hitam. Tepat pada tanggal 29 Oktober 1956, Lokananta resmi berdiri dengan nama lengkap Pabrik Piringan Hitam Lokananta Jawatan Radio Kementerian Penerangan Republik Indonesia di Surakarta. Sempat diusulkan bernama Indra Vox, singkatan dari Indonesia Raya Vox, nama Lokananta merujuk pada seperangkat gamelan surgawi dalam cerita pewayangan Jawa yang dapat berbunyi sendiri dengan nada yang indah (sumber: http://www.lokanantamusik.com/about). 


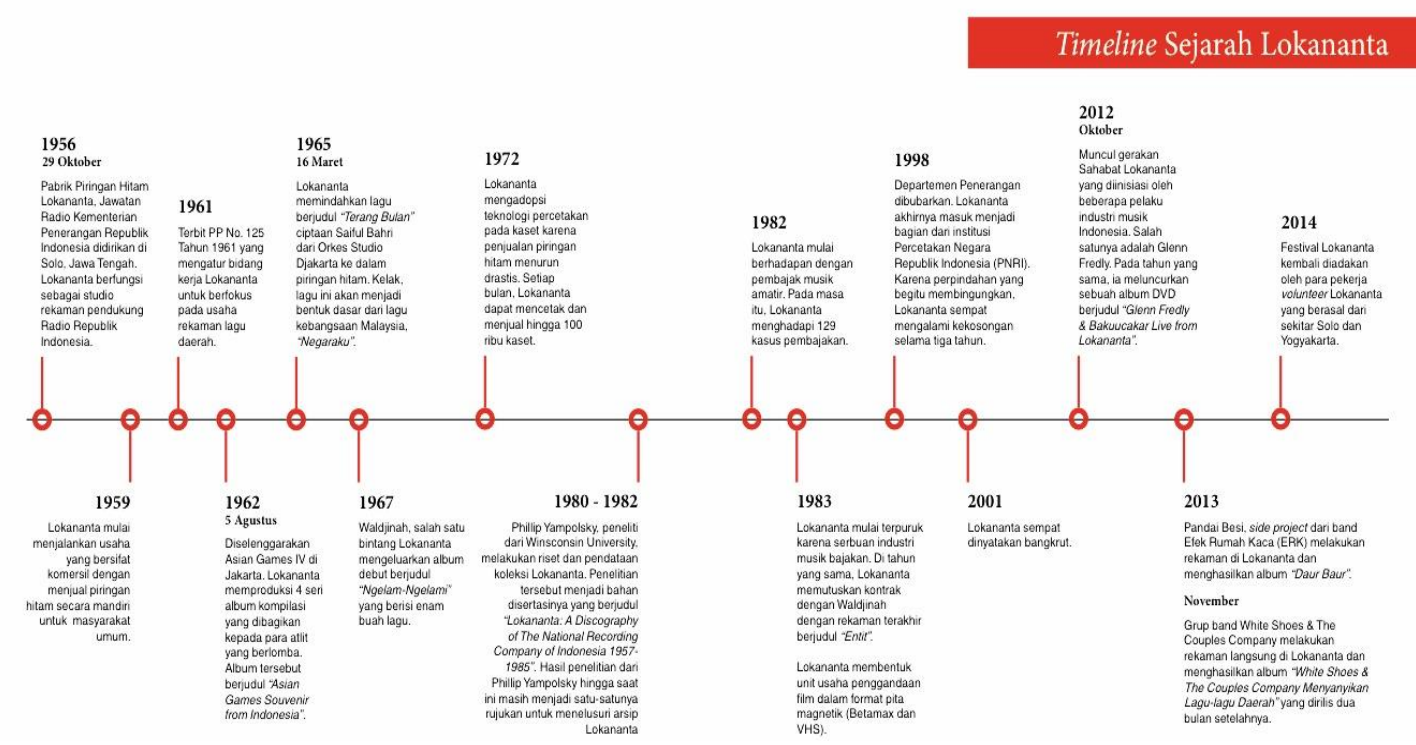

Gambar 1: Timeline Sejarah Lokananta

Sesuai Peraturan Pemerintah Nomor 215 Tahun 1961, bidang usaha Lokananta kemudian berkembang menjadi label rekaman dengan spesialisasi pada lagu daerah, pertunjukan kesenian, juga penerbitan buku dan majalah. Nama-nama besar seperti Gesang, Sam Saimun, Waldjinah, Buby Chen, dan Jack Lesmana pernah menjadi bagian dari institusi yang kemudian bernama Perusahaan Negara "Lokananta" ini. Selain koleksi lagu-lagu daerah, Lokananta juga menyimpan rekaman penting sejarah perjalanan bangsa Indonesia, seperti rekaman lagu kebangsaan "Indonesia Raya" versi instrumental gubahan Jos Cleber dengan durasi selama tiga stanza, serta pidato Ir. Soekarno saat pembukaan Konferensi Asia Afrika pertama di Bandung pada tahun 1955 (sumber: http://www.lokanantamusik.com/about).

Hingga akhir 80-an menjadi momen keemasan Lokananta. Keputusan untuk beralih format dari medium piringan hitam ke kaset pada tahun 1971 berbuah manis. Setiap bulan Lokananta mampu melepas 100 ribu keping kaset di pasaran dan disambut baik oleh publik. Pada tahun 1985, dengan diresmikan oleh Menteri Penerangan Harmoko, Lokananta memiliki studio seluas 375 meter persegi yang memungkinkan untuk menggelar rekaman live dengan tata akustik ruangan yang mumpuni. Pada tahun 1999 menjadi tahun kejatuhan dari Lokananta. Melalui Keputusan pemerintahan era Gus Dur membubarkan Departemen Penerangan pada tahun 1999 sehingga menjadi lonceng pengantar ajal Lokananta. Kurun waktu antara tahun 1999 hingga 2000 merupakan titik terkelam dalam perjalanan dari Lokananta, yakni harus berhenti berproduksi (sumber: http://www.lokanantamusik.com/about).

Harapan muncul kembali di tahun 2004. Sesuai dengan Keputusan Direksi Perum Percetakan Negara Republik Indonesia nomor 37/KEP/DIRPNRI/I/10/2004 tanggal 14 Oktober 2004, status Lokananta akhirnya mendapat kejelasan. Lokananta dilikuidasi dan sisa hasil likuidasi ditetapkan sebagai Penambahan Penyertaan Modal Negara Republik Indonesia ke dalam modal 
Perum Percetakan Negara Republik Indonesia (PNRI). Tiga tahun berselang, Lokananta kemudian menjadi bagian Perum PNRI dan namanya berubah menjadi Perum PNRI Cabang Surakarta-Lokananta. Cakupan tugasnya meliputi bidang multimedia, rekaman (kaset dan CD ROM), remastering, dan pengembangan percetakan dan jasa grafika serta kegiatan di dunia penyiaran (broadcasting). Usaha penyelamatan arsip sejarah kemudian mulai bergulir. Saat ini tercatat sudah ada 5 ribu master lagu dalam pita reel yang telah ditransfer dalam bentuk berkas digital (sumber: http://www.lokanantamusik.com/about).

Perlahan namun pasti, Lokananta saat ini berubah wujud menjadi wadah yang menampung energi seni dari lintas generasi. Mulai dari solois pop Glenn Fredly, sextet pop independen White Shoes and The Couples Company, grup ska/reggae Shaggydog, kolektif Pandai Besi, hingga duo eksperimental Senyawa menjadi representasi generasi musik Indonesia hari ini yang pernah mewarnai Lokananta. Lokananta juga memfasilitasi musisi-musisi independen yang ingin merilis format rekaman analog dalam bentuk kaset yang bisa diperbanyak sesuai keinginan. Selama tahun 2015, Lokananta menerima pesanan duplikasi kaset hingga 3 ribu keping tiap bulannya. Selain itu, Lokananta juga menyediakan tempat untuk pentas musik dan seni berbagai genre dan selalu membuka pintunya untuk kunjungan ke museum musik yang dikelolanya (sumber: http://www.lokanantamusik.com/about)

Sejak berdiri pada 1956 silam, tidak banyak yang berubah dari bangunan hingga peralatannya. Padahal sebagai perusahaan rekaman musik, seharusnya Lokananta mengikuti perkembangan zaman dan teknologi. Tapi masih banyak peralatan yang digunakan sejak '80-an hingga saat ini. Menurut Bembi Ananto salah satu karyawan di bagian mastering, sewaktu masih di bawah Departemen Penerangan, karyawan bebas memesan alat. Jadi alat-alat yang ada saat ini adalah alat-alat terbaik yang ada di Eropa. Intan Anggita Pratiwi, pemilik toko rilisan fisik Sub Store di Pasar Santa, Jakarta, merupakan salah satu dari sekian banyak pemerhati musik yang tidak tahan melihat kekunoan di Lokananta. Bersama Wendi, Sarah, Ajeng, Alain dan teman-temannya di Solo, Intan membuat gerakan bernama Sahabat Lokananta, untuk mempublikasikan kondisi Lokananta saat ini. Intan melihat sendiri studio rekaman yang selama ini sangat sarat akan cerita bersejarah. Tapi sekaligus sedih melihat kondisinya yang tidak terurus, yang lebih miris, masih dikatakan Intan, sebagian besar anak muda di Solo bahkan mengenal Lokananta sebagai tempat bermain futsal, bukan perusahaan rekaman yang legendaris. Alasan itu juga semakin membuat Intan dan teman-temannya bertekad sejarah Lokananta harus kembali diceritakan, agar tidak ada yang melupakannya (Putra, 2016)

Hadir pula Lokananta Project yang merupakan sebuah kolektif berisi penulis, fotografer, dan desainer muda yang membantu membuatkan situs dan buku Lokananta. Menurut mereka tugas mereka saat ini adalah bagaimana agar bisa tetap eksis pasca (buku dan situs) published. Eksis dalam artian terus membawa spirit dan isi bukunya. Fikry bersama dua orang sukarelawan lainnya Syaura Qotrunadha dan Fakhri Zakaria juga beberapa orang lainnya yang tergabung dalam Lokananta Project secara perlahan tapi pasti, akhirnya 
menyelesaikan buku dan situs untuk Lokananta dalam waktu dua tahun. Syaura adalah perintis proyek ini. Bermula dari penulisan buku dokumenter untuk kebutuhan tugas ujian akhir semester, secara perlahan gerakan ini berkembang dengan tujuan mulia, yakni agar publik bisa mengakses koleksi arsip Lokananta dengan lebih mudah. Terus bergerak sambil berbuat sesuatu menyuarakan gaung keberadaan perusahaan rekaman tertua di Indonesia ini, berbagai pihak seperti datang dan pergi membantu Lokananta. Tak ada lagi kisah sedih Lokananta yang diterlantarkan dan tak terurus. Dimulai dengan artikel karya Fakhri Zakaria dan Ayos Purwoaji di majalah Rolling Stone Indonesia pada Mei 2010 silam, lalu dilanjutkan dengan gerakan masif di media sosial menggunakan tagar \#SahabatLokananta dan \#SaveLokananta dua tahun setelahnya, beberapa musisi pun turut tergerak melakukan konser di Lokananta.

\section{Analisis}

Kini, mulai dari lembaga, perusahaan, institusi, perorangan yang menggunakan media sosial sebagai salah tools media dalam pemasaran semakin banyak. Namun, salah satu tantangan terbesar yang dihadapi para penanggung jawab komunikasi pemasaran saat ini adalah menentukan strategi komunikasinya dalam lingkungan dan lansekap media yang berubah. Pertanyaan kritis yang sering muncul adalah bagaimana mereka harus mengevaluasi kinerja media sosial dan membuktikan bahwa penggunaan media sosial lebih menguntungkan dibandingkan media tradisional. Cukup mudah bila pencapaian pemasaran melalui media sosial diukur dari peningkatan friends, fans dan follower. Benar bahwa metrik ini merupakan pencerminan dari kemampuan untuk membangkitkan kesadaran tentang merek. Banyaknya friends, fans dan follower memberikan gambaran apakah kampanye yang dilakukan suatu merek misalnya berhasil membangkitkan kesadaran dan mendapatkan perhatian dari publik. Sementara itu banyaknya orang yang menyatakan likes dan me-retweets yang diterimanya menunjukkan apakah upaya pemasaran yang dilakukan menimbulkan interest audience. Namun, sejatinya ada nilai lebih yang bisa dibangkitkan dari penggunaan media sosial, yakni meningkatkan keterlibatan (engagement), memberikan pengaruh dan memotivasi. Customer engagement merupakan salah satu metrik pengukuran yang paling penting. Engagement disini dapat berlangsung pada situasi offline maupun online baik di website bisnis dan situs jejaring sosial. Customer engagement dapat meningkatkan pemahaman konsumen tentang merek, juga membangun loyalitas pelanggan. Salah satunya sdalah user generated content dimana pelanggan didorong terlibat dalam kegiatan kampanye pemasaran. Selain itu, pelanggan juga didorong untuk menyebarkan informasi kampanye pemasaran. Untuk mengukur keterlibatan, beberapa praktisi pemasaran menggunakan komentar (di blog, Facebook, dll), re-tweets, waktu yang dihabiskan di situs web dan sebagainya. Memahami bagaimana hasil dari upaya pemasaran melalui media sosial terkait erat dengan kinerja bisnis menjadi sesuatu yang sangat penting pada saat penyusunan perencanaan strategi media social.

Seperti halnya dalam komunikasi pemasaran, tujuan yang ingin dicapai dengan menggunakan media social cukup bervariasi. Namun demikian, pada umumnya memiliki tujuan antara lain untuk penelitian pasar, termasuk 
memperoleh gambaran tentang preferensi dan persepsi konsumen terhadap produk atau merek; meningkatkan pemantauan dan respon terhadap krisis, termasuk upaya membalikkan dampak isu negatif pada merek atau organisasi ke positif dan meningkatkan citra. Media sosial juga bisa dimanfaatkan untuk meningkatkan jangkauan dan atau efektivitas upaya pemasaran, mengurangi biaya layanan pelanggan dan atau meningkatkan hasil layanan pelanggan, meningkatkan penjualan (dalam hal frekuensi, jangkauan atau hasil), untuk lebih memanusiawikan merek, menerobos pasar baru dengan teknologi yang lebih cerdas, meningkatkan hubungan pelanggan untuk membantu meningkatkan loyalitas pelanggan.

\section{Objective}

Lokananta mencoba untuk meluaskan pasar, dan memperkenalkan keberadaannya kepada masyarakat yang lebih luas. Alasannya, semakin sedikit orang yang mengenal Lokananta. Padahal dari sisi historis Lokananta memliki kisah yang panjang dan bahkan memiliki kontribusi dalam perjalanan sejarah musik di Indonesia. Selain itu Lokananta juga ingin memperkenalkan produk dan layanan yang dimilikinya mulai dari piringan hitam, kaset, penggandaan kaset, ruang kreatif, penggandaan compact disc, hingga recording.

\section{Strategy}

Strategi yang dilakukan oleh Lokananta untuk meluaskan pasar adalah dengan melakukan komunikasi. Komunikasi ini dilakukan dengan menggunakan beberapa medium. Medium pertama adalah activation. Activation yang diselenggarakan melibatkan audiens dengan karakteristik sesuai target pasar Lokananta. Strategi kedua adalah komunikasi yang dilakukan melalui media sosial yang banyak digunakan oleh anak muda. Kedua medium ini dianggap oleh Lokananta sangat tepat digunakan.

\section{Taktik}

Agar strategi yang dijalankan dapat berjalan sesuai dengan tujuan, maka Lokananta mendesain activation yang melibatkan anak muda dan dianggap sesuai dengan karakterisitik anak muda. Sementara itu untuk media sosial digunakan Instagram. Instagram dipilih karena anak media sosial ini memiliki elemen teks dan visual, sehingga menarik bagi para penggunanya. Media sosial ini tidak hanya mendistrbusikan konten berupa kegiatan activation Lokananta, tetapi juga produk dan jasa yang ditawarkan oleh Lokananta.

\section{Action}

Di sisi ini, Lokananta tidak segan untuk melakukan ataupun menyelenggarakan kegiatan seperti peluncuran album musik indie, pameran komik, kompetisi melukis di atas vinyl, hingga kegiatan otomotif yang menarik perhatian anak muda. Ini dengan cara berkolaborasi dengan berbagi kantung budaya, komunitas, hingga organisasi lainnya. Pada kesempatan inilah Lokananta memperkenalkan keberadaan Lokananta kepada audiens yang hadir. Di sini tidak hanya ada sosialisasi tetapi juga interaksi secara langsung dengan audiens. 
Sementara itu, untuk media sosial, Lokananta mendistribusikan informasi kegiatan-kegiatan tersebut agar diketahui oleh para follower akun Instagram Lokananta. Selain informasi mengenai activation yang dilakukan, Lokananta juga menginformasikan produk dan jasa yang ditawarkan oleh Lokananta, seperti jasa penggandaan kaset, rekaman, ruang kreatif, hingga co-working space. Bahkan distribusi konten apresiasi terhadap tokoh musik nasional juga dilakukan, misalnya hari kelahiran Ismail Marzuki.

\section{Control}

Setelah menjalankan tahapan di atas terlihat komunikasi brand activation dan media sosial terlihat membuahkan hasil. Beberapa hasil tersebut dapat digambarkan secara garis besar seperti berikut: dari sisi brand activation terlihat permintaan untuk melakukan activation di Lokananta meningkat. Permintaan berkolaborasi menggunakan ruang kreatif di Lokananta semakin sering datang, baik dari Solo, Yogyakarta, maupun Semarang. Bahkan permintaan kehadiran Lokananta di beberapa event di luar ketiga kota tersebut juga bertambah, misalnya saja pada acara peluncuran album band indie, atau cassete store day dibeberapa kota seperti Bandung dan Jakarta. Bahkan kolaborasi dengan pihak kampus pun terjadi. Ini biasanya untuk keperluan kajian, baik untuk tesis maupun skripsi.

Dari sisi media sosial, konten yang didisitribusikan terihat memiliki like. Meskipun jumlah like yang tinggi terlihat pada konten-konten tertentu. Konten dengan like yang tinggi biasanya konten yang sesuai dengan karakter audiens atau follower tertentu, misalnya saja konten yang berbau band indie lebih banyak memperoleh "like" dari anak muda, sedangkan konten berisi lagu nasional misalnya lebih banyak memperoleh "like" dari follower di usia 50-tahunan.

Diperdalam pemaparan oleh Nugroho (pemain musik, pengajar, dan pengumpul rilisan musik) sebagai berikut:

"Perkembangan perusahaan rekaman atau label rekaman musik di Indonesia dewasa ini telah berkembang pesat sehingga menghasilkan beberapa musisi ternama dan lagu-lagu populer di Indonesia. Hal tersebut tidak terlepas dari peran penting perusahaan rekaman dalam pendokumentasian musik ke dalam format audio. Berbagai jenis dan aliran musik yang hadir mewarnai kancah musik di Indonesia tersebar popularitasnya melalui dua jalur rekaman, yaitu Major Lable dan Indie Lable. Major Lable adalah perusahaan rekaman musik besar yang lebih bertujuan untuk menghasilkan keuntungan besar (money oriented) dan memenuhi kebutuhan pasar industri musik, sedangkan Indie Lable sesuai dengan namanya indie yang diambil dari kata independent yang didanai secara independen dan mengutamakan idealis kreatifitas dalam bermusik. Salah satu pionir perusahaan rekaman yang hadir pertama kali di Indonesia adalah Lokananta, Surakarta”.

Teknologi rekaman pada saat ini pun mulai berkembang dari era analog menjadi era digital dengan adanya perangkat-perangkat lunak (software) rekaman yang lebih praktis digunakan. Selain itu, perusahaan-perusahaan rekaman swasta di Indonesia kian bermunculan sehingga memaksa Lokananta untuk bersaing dalam industri musik Indonesia. Kurangnya kepedulian akan menjaga serta melestarikan aset bersejarah sepertinya masih menjadi nilai minus di Indonesia. 
Ribuan keping rekaman pun tidak terawat, ironisnya pemerintah maupun masyarakat tidak mengetahui bahwa kelak Lokananta akan memiliki nilai sejarah yang sangat tinggi jika pemerintah memberi dukungan lebih untuk Lokananta.

Perusahaan rekaman musik besar dan tantangan kemajuan teknologi yang lebih mengedepankan teknologi digital menjadi permasalahan penting bagi Lokananta dalam bersaing di industri musik di Indonesia. Kini Lokananta kembali dan menarik perhatian musisi-musisi Indonesia maupun pergerakan-pergerakan kecil masyarakat melalui media sosial dalam tagar \#SaveLokananta yang ditujukan untuk masyarakat dan pemerintah akan pentingnya melestarikan sejarah musik Indonesia.

"Bicara sejarah eperti yang saya ingat di era 80an hampir semua perusahaan rekaman di Indonesia termasuk Musica Studios sebetulnya sudah tidak lagi memproduksi album rekaman dalam bentuk vinyl atau piringan hitam. Tapi untuk mendistribusikan album album produksi mereka ke berbagai stasiun radio sebagai alat promosi, para label di Indonesia masih mencetak piringan hitam dalam jumlah terbatas. Biasanya untuk satu album, para label mencetak sekitar 1000 keping piringan hitam yang kemudian dibagi-bagikan secara gratis ke stasiun radio swasta yang berada dibawah naungan PRSSNI. Beberapa stasiun radio malah tidakm memutar format piringan hitam tersebut karena mereka merasa lebih praktis jika memutar atau mengudarakan lagu dengan menggunakan format kaset yang massal. Piringan hitam yang kerap disebut Promo".

Nugroho memberikan pandangannya bahwa kembalinya piringan hitam ini adalah sebuah kerinduan masa lalu. Menurutnya budaya itu adalah sebuah siklus yang terus berputar, bisa saja sesuatu yang telah lama dilupakan akan muncul dan digemari lagi. Tren piringan hitam ini menurutnya juga terjadi di luar negeri. Menurut Nugroho yang menarik dari piringan hitam ini adalah keinginan untuk menikmati sesuatu yang sifatnya vintage atau masa lalu. Kerinduan itulah yang diantisipasi oleh label-label rekaman di Eropa. "Sesuatu yang dirasakan unik dan indah, kalau lagu itu bening suaranya, dan keindahan itu juga tercermin di covernya," jelasnya.

Piringan hitam pernah populer tahun 1980, tapi sempat menghilang pada 1980an karena terganti dengan kaset, kemudian ditinggalkan orang. Pemutarnya pun juga tidak banyak diproduksi. Akhirnya orang beralih ke era digital, dan bentuk fisik pun mulai ditinggalkan. "Begitu muncul lagi inikan jadi vintage, menjadi unik dan kuno," jelasnya. Jika berbicara mengenai kualitas suara, menurutnya tak jauh berbeda. Hanya saja jika dibandingkan dengan kaset piringan hitam ini jauh lebih awet dan mudah dirawat. Kesempatan ini yang harus manfaatkan secara maksimal oleh Lokananta mengedukasi generasi muda melalui media-media baru dan jejaringnya.

\section{Simpulan}

Berdasarkan studi kasus yang dilakukan penulis terhadap topik penelitian, diperoleh kesimpulan penelitian, melalui kajian terhadap sumber data penelitian, baik primer maupun sekunder, penulis menemukan bahwa terdapat beberapa cara 
yang dapat dikatakan ideal dalam analisis komunikasi brand activation dan media digital untuk mempertahankan eksistensi Brand Lokananta Record, dapatlah disimpulan sebagai beriku:

1. Dimana perlunya memaksimal medium-medium baru yang makin marak untuk berkomunikasi dan mewartakan ke generasi muda.

2. Perlunya melakukan inovasi baru di Lokananta sendiri dengan pendekatan kreatif dan kekinian.

3. Perlu melakukan dan menjadi jejaring komunitas pecinta lokananta.

Bersandar pada hasil penelitian ini, penulis pun mengajukan saran yang diharapkan mampu memberikan manfaat positif yang signifikan bagi pihak- pihak terkait. Saran dibagi ke dalam dua bagian, yakni saran khusus bagi Perusahaan Rekaman Lokananta; Agar berani melakukan terobosan-terobosan baru dan menghidupkan kembali kejayaan Lokananta seperti dimasa keemasannya.

\section{Ucapan Terima Kasih}

Ucapan terima kasih penulis tujukan kepada seluruh narasumber yang telah bersedia untuk bekerja sama selama penelitian ini berlangsung. Terima kasih juga diberikan kepada DPPM Untar yang telah memberikan dana hibah penelitian, sehingga penelitian ini dapat terlaksana.

\section{Daftar Pusataka}

Cangara, Hafied. (2017). Perencanaan dan Strategi Komunikasi. Jakarta : Rajawali Press.

Djaslim, Saladin dan Yevis Marty Oesman. (2002). Intisari Pemasaran dan Unsur - Unsur Pemasaran, $2^{\text {nd }}$ Ed. Bandung : Penerbit Linda Karya.

Kasali, Rhenald. (2017). Disruption. Jakarta : Gramedia Pusataka Utama.

Kertajaya. (2017). Marketing Changes in Challengging Times. Jakarta : Gramedia Pustaka Utama dan Markplus. Inc.

Lim, Hendrik. (2016). New Games, New response, Strategy to Win The Market Change. Jakarta : Defora Publisher.

Prodjo, Wahyu Adityo. (2015). Mencari Kepingan Sejarah Musik di Lokananta. Kompas Online. https://travel.kompas.com/read/2015/02/08/130400127/Mencari.Kepingan . Sejarah.Musik.di.Lokananta?page $=$ all

Putra, Muhammad Andika. (2016), Bahu Membahu, Peduli Lokananta. CNN

Online. https://www.cnnindonesia.com/hiburan/20160416081632-227124327/bahu-membahu-peduli-lokananta

Saeed, Rashid, (2015). Brand Activation, A Theoritical Perspetive. Journal of Marketing and Consumer Researh.

Semiawan, Conny. (2010). Metode Penelitian Kualitatif. Jakarta : Grasindo.

Surmawan, Ujang., dkk. (2010). Pemasaran Strategik, Perspektif Value Based Marketing dan Pengukuran kerja. Bogor : IPB Pers.

Survey Sumber Informasi Remaja di 10 Kota besar, Marketeer, Agustus, 2019 
Yulianita, Neni., \& Leksono, Ninok. (2011) Corporate and Marketing Communication. Bandung : Asosiasi Pendidikan Ilmu Komunikasi. 